Western North American Naturalist 69(4), (C) 2009, pp. 469-474

\title{
SUMMER BURROWS OF ORD'S KANGAROO RATS (DIPODOMYS ORDII) IN WESTERN NEBRASKA: FOOD CONTENT AND STRUCTURE
}

\author{
Jeremy A. White1,2
}

\begin{abstract}
Extent of larder hoarding differs among species of kangaroo rats, and limited information is available for food stored in burrows by Ord's kangaroo rat (Dipodomys ordii) — the most widespread species of Dipodomys. I excavated 9 burrows recently used by adult $D$. ordii during summer in the Sandhill Region of Nebraska. I observed only small quantities of food stored in burrows. Eight of 9 burrows contained segments of sand dropseed (Sporobolus cryptandrus) in limited quantities. These segments consisted of upper leaves with fruits (containing seeds) housed in sheaths. My observations represent the first documentation of $D$. ordii storing food in burrows under natural conditions. Compared to the burrows of other species of kangaroo rat, burrows of $D$. ordii were simple in structure with 1 main tunnel and 1-3 entrances. In summer, Ord's kangaroo rats commonly harvest seeds from plants in the Sandhill Region of Nebraska, but individuals apparently do not store large quantities of food in burrows, which suggests they store food in scatter hoards during this season.
\end{abstract}

Key words: Dipodomys ordii, kangaroo rat, burrows, food hoarding, foraging, Nebraska, Sporobolus cryptandrus.

Kangaroo rats (Dipodomys) are nocturnal, semifossorial rodents that inhabit arid and semiarid regions of western North America (Schmidly et al. 1993). Individuals spend most of the diel cycle in burrows and only engage in short-duration bouts aboveground during periods of darkness (Schroder 1979, Langford 1983). The diet of kangaroo rats is composed mainly of seeds (Reichman 1975), and individuals store seeds for future use in burrows (larder hoards), subsurface caches (scatter hoards), or both (Vorhies and Taylor 1922, Shaw 1934, Hawbecker 1940, Reynolds 1958, Daly et al. 1992, Jenkins and Breck 1998, Price et al. 2000). Food-hoarding strategies vary among species of kangaroo rats and have implications for other aspects of their behavior and ecology.

Although large kangaroo rats usually are described as larder hoarders and smaller ones as scatter hoarders (Reichman and Price 1993), studies in laboratory arenas demonstrate that both small kangaroo rats (Dipodomys merriami and Dipodomys ordii) and large kangaroo rats (Dipodomys microps, Dipodomys panamintinus, Dipodomys deserti, and Dipodomys spectabilis) scatter hoard and larder hoard seeds (Jenkins and Breck 1998, Price et al. 2000). Both caching patterns also were observed in natural environments with Dipodomys ingens
(Shaw 1934), Dipodomys venustus (Hawbecker 1940), D. microps (Breck and Jenkins 1997), and D. merriami (Daly et al. 1992, Breck and Jenkins 1997, Leaver and Daly 2001, Longland et al. 2001); but field studies of food hoarding for most species of Dipodomys are lacking. Investigations of food storage for freeliving animals are important for comparison with laboratory studies because in some situations food-hoarding rodents use different foraging and hoarding strategies in field settings compared to laboratory settings (Leaver and Daly 1998, Ovadia et al. 2001, Leaver 2004).

To date, little information is known about food-hoarding behaviors of Ord's kangaroo rat (D. ordii) - the most widespread species of Dipodomys. A laboratory study with individuals from Nevada suggests that $D$. ordii is primarily a larder hoarder because most seeds collected by individuals were stored in burrows (Jenkins and Breck 1998). In addition, Langford (1983) observed D. ordii defending its burrows under natural conditions in Utah, which further supports the contention that this species is primarily a larder hoarder.

Although observations from the laboratory and field suggest that $D$. ordii exhibits larderhoarding behaviors, no published study has reported whether it stores food in burrows in

${ }^{1}$ Department of Biological Sciences, Auburn University, Auburn, AL 36849

${ }^{2}$ Present address: Department of Biology, University of Nebraska at Omaha, NE 68182. E-mail: jeremywhite@unomaha.edu 


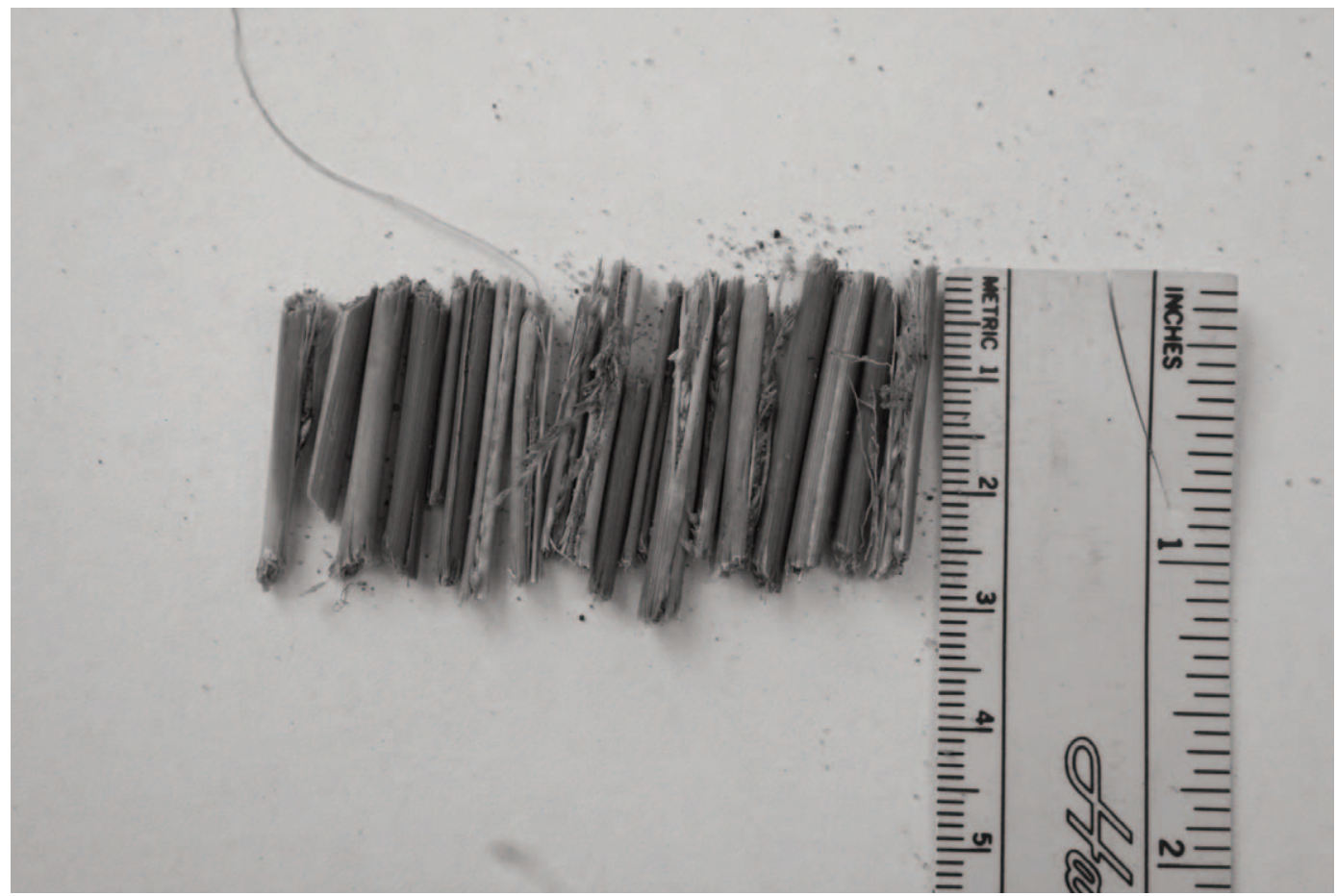

Fig. 1. Cut leaf sheaths of sand dropseed (Sporobolus cryptandrus) stored in burrows of Ord's kangaroo rats (Dipodomys ordii) in the Sandhill Region of Nebraska, July and August 2007. Segments of upper leaves contained fruits enclosed in sheaths.

the wild. Some evidence indicates that $D$. ordii might not larder hoard seeds under natural conditions, at least during certain seasons. For example, 2 studies documented burrow structure of $D$. ordii in Idaho, but neither study mentioned whether food was present in burrows (Reynolds and Wakkinen 1987, Laundré and Reynolds 1993). Also, D. ordii in Nebraska commonly used multiple burrows during summer, and thus occupancy of any one burrow in this population was periodic (White 2008). This situation makes larder hoarding risky because large, undefended stores of seeds in burrows are susceptible to pilferers (Vander Wall et al. 2005).

For this study, I determined whether $D$. ordii stored food in burrows during summer at a site in western Nebraska. I also present details on structure of burrows inhabited by $D$. ordii at the study site.

\section{Methods}

I conducted my study at Crescent Lake National Wildlife Refuge in Garden County,
Nebraska. This refuge is located in the Sandhill Region of Nebraska - an area dominated by sand dunes covered in grasses, forbs, and shrubs (Whitcomb 1989). Common vegetation on dunes included sand bluestem (Andropogon hallii), sand muhly (Muhlenbergia arenicola), prairie sandreed (Calamovilfa longifolia), sand dropseed (Sporobolus cryptandrus), needle and thread (Stipa comata), sunflowers (Helianthus), blazing star (Mentzelia), sandcherry (Prunus pumila), and soapweed yucca (Yucca glauca). Soils in the region are composed of sand mixed with 1-4\% silt and clay (Whitcomb 1989). Summers are warm (average maximum temperature for July $=30.7^{\circ} \mathrm{C}$ ) and winters are cold (average minimum temperature for January $=-12.9^{\circ} \mathrm{C}$ ), and more than $80 \%$ of precipitation falls from April to September (Wilhite and Hubbard 1989). Dipodomys ordii is abundant in the Sandhill Region of Nebraska and is the only species of kangaroo rat in the area (Jones et al. 1983).

To document whether $D$. ordii stored food in its burrows, I used radiotelemetry to identify burrows used by kangaroo rats (see methods 
TABLE 1. Food content of 9 burrows occupied by adult Dipodomys ordii in summer in western Nebraska. Numbers in parentheses are the number of cut upper sheaths of leaves (containing fruits) of sand dropseed (Sporobolus cryptandrus) stored in burrows.

\begin{tabular}{|c|c|c|c|c|c|}
\hline $\begin{array}{l}\text { Individual } \\
(\text { eartag \#) }\end{array}$ & Sex & $\begin{array}{l}\text { Reproductive } \\
\text { condition }\end{array}$ & $\begin{array}{l}\text { Days since burrow } \\
\text { was occupied }\end{array}$ & $\begin{array}{c}\text { Presence } \\
\text { of food }\end{array}$ & $\begin{array}{c}\text { Quantity of } \\
\text { sand dropseed }\end{array}$ \\
\hline 826 & $\sigma$ & nonscrotal & 8 & yes $^{a}$ & small (137) \\
\hline 831 & $\sigma$ & scrotal & 0 & yes $^{\mathrm{a}}$ & small (88) \\
\hline 836 & $\sigma$ & scrotal & 2 & yes ${ }^{b}$ & small (71) \\
\hline 833 & 우 & postlactating & 3 & yes $^{\mathrm{a}}$ & small (145) \\
\hline 987 & 우 & postlactating & 0 & yes ${ }^{c}$ & small \\
\hline 987 & 우 & postlactating & 10 & no & - \\
\hline 841 & 우 & postlactating & 0 & yes $^{\mathrm{d}}$ & small (67) \\
\hline 841 & 우 & postlactating & 9 & yes $^{\mathrm{a}}$ & small \\
\hline 841 & q & postlactating & 6 & yes $^{\mathrm{a}}$ & small \\
\hline
\end{tabular}

Sand dropseed (Sporobolus cryptandrus) only.

${ }^{\mathrm{b}}$ Sand dropseed and spikelets $(<50)$ of sixweeks fescue (Festuca octoflora).

'Sand dropseed, spikelets ( $<50)$ of sixweeks fescue, and fruits $(<25)$ of peppergrass (Lepidium densiflorum).

dSand dropseed and spikelets (<25) of Schweinitz's flatsedge (Cyperus schweinitzii).

in White 2008). I excavated burrows within 10 days of occupancy by a kangaroo rat $(27$ July-16 August 2007). During excavation, tunnels in burrows remained intact due to soil moisture from rain at the study site (7 rain events from 27 July to 16 August) and small quantities of silt and clay in the soil (Whitcomb 1989). I identified, quantified, and collected food items in burrows. Presence of nests in burrows also was recorded. In addition, I measured and recorded various attributes of burrow structure including number of entrances, height and width of entrances, height and width of main tunnels, length and depth of main tunnels, as well as length of any side tunnels.

\section{Results}

I excavated 9 burrows recently occupied by 6 different adult Ord's kangaroo rats (3 males and 3 females), and I observed food in 8 burrows, albeit small quantities. Stored food mainly consisted of leaf sheaths of sand dropseed cut into short segments (ca. 2-3 cm in length; Fig. 1). Fruits (containing seeds) were attached to branches of panicles in cut sheaths of upper leaves. Five burrows contained only sheaths of sand dropseed, and 3 burrows contained sheaths of sand dropseed along with small quantities of other items, including spikelets of sixweeks fescue (Festuca octoflora) and Schweinitz's flatsedge (Cyperus schweinitzii) and fruits of peppergrass (Lepidium densiflorum; Table 1).

Most burrows used by $D$. ordii as daytime retreats in summer were simple in structure and consisted of only one main tunnel with either an enlarged area off the main tunnel (an evagination) or a single, shorter side tunnel (Table 2). However, 1 burrow was more complex and consisted of a main tunnel, 2 side tunnels, and a nest chamber (Table 2). Simple burrows included a small entrance that widened into a main tunnel as the burrow descended, and the main tunnel narrowed again as it ascended back to the surface (Table 2). In 5 burrows, the ascending portion of the tunnel ended in another opening. Three burrows had only one opening with the other end of the tunnel terminating about $5 \mathrm{~cm}$ below the surface of the ground, with no indication that it had been used as an entrance (i.e., it was not an entrance plugged with sand). In 7 burrows, an evagination was present before tunnels ascended to the surface, and in 1 burrow, a side tunnel was present. Small quantities of food were observed stored in evaginations, lying on floors of main tunnels, or pushed into walls of main tunnels (Table 2).

The most complex burrow (first burrow of individual 987) was used by a recently lactating female (she was lactating 10 days prior to excavation of the burrow). Her burrow consisted of a main tunnel with entrances at either end and 2 side tunnels (Table 2). One side tunnel ended in a third entrance, and the other terminated just below the surface. Small quantities of food were present in the wall of one side tunnel and on the floor of the main tunnel (Table 2). This burrow also contained a nest chamber: a separate, spherical room connected to the main tunnel. The room contained a nest that lined the bottom of the chamber, and the 
TABLE 2. Burrow structure and location of food in 9 burrows occupied by adult Dipodomys ordii in summer in western Nebraska. Only one opening was measured for burrows with more than one entrance. Height and width of the main tunnel were measured at the deepest portion of the tunnel (i.e., not near entrances).

\begin{tabular}{|c|c|c|c|c|c|c|c|c|}
\hline \multirow{2}{*}{$\begin{array}{l}\text { Individual } \\
\text { (ear tag \#) }\end{array}$} & \multirow[b]{2}{*}{ Entrances } & \multicolumn{2}{|c|}{ Entrance $(\mathrm{cm})$} & \multicolumn{4}{|c|}{ Main tunnel $(\mathrm{cm})$} & \multirow[b]{2}{*}{ Burrow features } \\
\hline & & Width & Height & Width & Height & Length & Depth & \\
\hline 826 & 2 & 3.5 & 4.0 & - & - & 130 & 50 & evagination $^{\mathrm{a}}$ \\
\hline 831 & 2 & - & - & - & - & 540 & - & 1 side tunnelc \\
\hline 836 & 1 & 3.5 & 5.0 & 7.0 & 11.0 & 220 & 45 & evagination ${ }^{\mathrm{e}}$ \\
\hline 833 & 1 & 3.2 & 4.2 & - & 一 & 265 & 35 & evagination $^{\mathrm{a}}$ \\
\hline 987 & 3 & - & - & - & 一 & 380 & 65 & 2 side tunnels ${ }^{f}$ \\
\hline 987 & 2 & - & - & - & - & 330 & 50 & evagination ${ }^{\mathrm{h}}$ \\
\hline 841 & 1 & 3.5 & 4.5 & - & - & 250 & 40 & evaginationg \\
\hline 841 & 2 & - & - & 10.0 & 8.0 & 280 & 45 & evagination ${ }^{b}$ \\
\hline 841 & 2 & 3.5 & 3.0 & 10.0 & 7.0 & 320 & 35 & evagination $^{\mathrm{d}}$ \\
\hline
\end{tabular}

bSand dropseed lying on floor of main tunnel.

'Sand dropseed lying on floor of main tunnel; length of side tunnel not measured.

dSand dropseed pushed into wall of main tunnel.

esand dropseed in evagination and sand dropseed and sixweeks fescue lying on floor of main tunnel.

fSand dropseed and sixweeks fescue lying on floor of main tunnel and sixweeks fescue and peppergrass pushed into wall of side tunnel. Side tunnels measured $100 \mathrm{~cm}$ and $210 \mathrm{~cm}$ in length, and a nest was present in a nest chamber.

gSand dropseed and Schweinitz's flatsedge lying on the floor of the main tunnel.

$\mathrm{h}_{\mathrm{No}}$ food in burrow.

contents consisted mainly of unidentifiable shredded sheaths of grasses, although intact florets of some grasses included needle and thread, sixweeks fescue, cheatgrass (Bromus tectorum), and blue grama (Bouteloua gracilis). Also, I observed 6 intact seeds and seed coat fragments of soapweed yucca in the nest.

\section{Discussion}

Ord's kangaroo rats did not maintain large accumulations of food inside burrows in late July and early August in the Sandhill Region of Nebraska, although relatively small quantities of leaf sheaths with fruits of sand dropseed were observed in $89 \%$ of burrows. Ord's kangaroo rats and Merriam's kangaroo rats are known to cut and consume tillers of mesa dropseed (Sporobolus flexuosus) and other grasses (Kerley et al. 1997, Sipos et al. 2002), but to my knowledge this is the first published report of $D$. ordii storing grasses or other food under natural conditions. Others have observed banner-tailed kangaroo rats storing cuttings of sand dropseed (Vorhies and Taylor 1922, Schroder 1979, Herrera et al. 2001). Investigators referred to these cuttings as "cut sections of the stems" in which "heads of S. cryptandrus are retained to a great extent within the leaf sheaths" (Vorhies and Taylor 1922), upper stems that were "stored before the seed heads emerged from their sheaths" (Schroder 1979), or "seed stems" (Herrera et al. 2001).
Total number of sheaths in burrows of $D$. ordii (67-145) was considerably less than amounts in burrow systems of banner-tailed kangaroo rats (D. spectabilis; 680,000); however, the mound of D. spectabilis was excavated in November (Vorhies and Taylor 1922). Many segments are cut and stored by $D$. spectabilis from August to October (Herrera et al. 2001), so perhaps in late summer and autumn, $D$. ordii also would accumulate large caches of sand dropseed or other items in burrows. By cutting seeds or other material directly from plants instead of searching for scattered seeds on the surface of the ground, kangaroo rats may minimize time spent foraging (Schroder 1979). Besides cutting leaf sheaths of sand dropseed, D. ordii in Nebraska also chewed into pods of soapweed yucca to collect seeds (J.A. White, personal observation) and clipped seed-filled heads of sunflowers (Lemen and Freeman 1985). I excavated burrows before seeds of yucca and sunflowers became mature in the Sandhills, thus $D$. ordii may store these resources in burrows in greater quantities during the late summer, autumn, and winter once these seeds become ripe.

In summer, burrows used by Ord's kangaroo rats in western Nebraska were simple in structure and usually (89\%) consisted of 1 main tunnel with 1-2 entrances. Burrows in Nebraska were deeper (46 versus $34 \mathrm{~cm}$ ) and longer (336 versus $253 \mathrm{~cm}$, including side tunnels) on 
average than those of $D$. ordii in Idaho, but Reynolds and Wakkinen (1987) did not report on number of entrances or number of side tunnels for the population in Idaho. Burrows in Nebraska may be simpler than those used by $D$. ordii in Utah; Langford (1983) reported that males used extensive main burrows in spring but gave no details of structure.

Although burrows of $D$. ordii in Nebraska were relatively simple in structure, they shared features with burrows of other species of kangaroo rats, including enlarged areas off main tunnels (evaginations), tunnels that terminated below the surface of the ground, and nest chambers. Evaginations, which were observed in most burrows (78\%) of $D$. ordii, also have been described in burrows of other species of kangaroo rats; these sites generally are used for food storage (Vorhies and Taylor 1922, Hawbecker 1940, Tappe 1941) or resting areas (Tappe 1941, Kenagy 1973). Only 3 of 7 evaginations in burrows of $D$. ordii in Nebraska contained stored food, so the purpose of these areas remains unclear. It is also possible that evaginations are the remains of tunnels previously filled with sand, as I only observed side tunnels or evaginations but never both in burrows. Similar to Dipodomys heermanni (Tappe 1941) and D. venustus (Hawbecker 1940), D. ordii in Nebraska constructed tunnels that terminated just below the surface of the ground (44\%). These tunnels likely provide a means of escape for D. ordii. During excavation of burrows, other researchers observed kangaroo rats breaking through to the surface from these tunnels and fleeing to nearby burrows, indicating that these shallow-ending tunnels provided escape routes (Hawbecker 1940, Tappe 1941). A nest chamber containing a nest was observed in only one burrow (11\%), which was inhabited by a recently lactating female. In summer, nests likely are constructed by female $D$. ordii for raising young. Nest-building occurs just before parturition in kangaroo rats (Eisenberg 1993), and nests lining the bottom of nest chambers in burrows of $D$. heermanni were used for raising young (Tappe 1941). In temperate regions of California, D. microps and $D$. merriami construct nests for insulation in winter (Kenagy 1973). In Nebraska, nests also might be constructed by $D$. ordii in winter for insulation.

To date, most evidence of food hoarding by kangaroo rats in the laboratory (Jenkins and
Breck 1998, Price et al. 2000) and in the field (Shaw 1934, Hawbecker 1940, Daly et al. 1992) suggests that individuals store seeds in both larder hoards and scatter hoards. Ord's kangaroo rats in Nebraska stored small quantities of food in their burrows, but the lack of an elaborate and extensive larder hoard indicates they also may store food in scatter hoards in summer. In a laboratory study in Nevada, $D$. ordii mainly larder hoarded seeds (Jenkins and Breck 1998). However, comparisons between these studies are difficult because my data are limited to July and August, whereas individuals were tested throughout the year in the laboratory study (Jenkins and Breck 1998). Investigations of food-hoarding and burrow-use behaviors of Ord's kangaroo rats are warranted in other seasons, especially in free-living populations.

\section{ACKNOWLEDGMENTS}

I thank Neil Powers and Marlin French at Crescent Lake National Wildlife Refuge for providing housing and use of refuge property during this study. I also thank David M. Sutherland for assistance with identifying plant material and for informative discussions on terminology of vegetation. Troy L. Best, Robert S. Lishak, Michael C. Wooten, and 2 anonymous reviewers provided valuable comments on earlier versions of this manuscript. Partial funding for this research was provided by the graduate school at Auburn University and the Alabama Academy of Science.

\section{Literature Cited}

Breck, S.W., And S.H. Jenkins. 1997. Use of an ecotone to test the effects of soil and desert rodents on the distribution of Indian ricegrass. Ecography 20: 253-263.

Daly, M., L.F. Jacobs, M.I. Wilson, and P.R. Behrends. 1992. Scatter-hoarding by kangaroo rats (Dipodomys merriami) and pilferage from their caches. Behavioral Ecology 3:102-111.

EisenberG, J.F. 1993. Ontogeny. Pages 479-490 in H.H. Genoways and J.H. Brown, editors, Biology of the Heteromyidae. Special Publication, American Society of Mammalogists 10. 719 pp.

HawBECKER, A.C. 1940. The burrowing and feeding habits of Dipodomys venustus. Journal of Mammalogy 21: 388-396.

Herrera, J.K., L. Ensz, And A.L. WiLKe. 2001. Stacking of seeds changes spoilage dynamics of food caches of the banner-tailed kangaroo rat (Dipodomys spectabilis). Journal of Mammalogy 82:558-566.

Jenkins, S.H., AND S.W. BRECK. 1998. Differences in food hoarding among six species of heteromyid rodents. Journal of Mammalogy 79:1221-1233. 
Jones, J.K., Jr., D.M. Armstrong, R.S. Hoffmann, And C. JonEs. 1983. Mammals of the northern Great Plains. University of Nebraska Press, Nebraska.

Kenagy, G.J. 1973. Daily and seasonal patterns of activity and energetics in a heteromyid rodent community. Ecology 54:1201-1219.

Kerley, G.I.H., W.G. Whitford, and F.R. Kay. 1997. Mechanisms for the keystone status of kangaroo rats: graminivory rather than granivory? Oecologia (Berlin) 111:422-428.

LANGFORD, A.L. 1983. Pattern of nocturnal activity of male Dipodomys ordii (Heteromyidae). Southwestern Naturalist 28:341-346.

LAundRÉ, J.W., AND T.D. REYNOLDS. 1993. Effects of soil structure on burrow characteristics of five small mammal species. Great Basin Naturalist 53:358-366.

LEAVER, L.A. 2004. Effects of food value, predation risk, and pilferage on the caching decisions of Dipodomys merriami. Behavioral Ecology 15:729-734.

LEaver, L.A., AND M. DaLy. 1998. Effects of food preference on scatter-hoarding by kangaroo rats (Dipodomys merriami . Behaviour 135:823-832.

2001. Food caching and differential cache pilferage: a field study of coexistence of sympatric kangaroo rats and pocket mice. Oecologia (Berlin) 128: $577-584$.

Lemen, C.A., And P.W. Freeman. 1985. Tracking mammals with fluorescent pigments: a new technique. Journal of Mammalogy 66:134-136.

Longland, W.S., S.H. Jenkins, S.B. Vander Wall, J.A. VEECH, AND S. PYARE. 2001. Seedling recruitment in Oryzopsis hymenoides: are desert granivores mutualists or predators? Ecology 82:3131-3148.

Ovadia, O., Y. Ziv, Z. Abramsky, B. Pinshow, and B.P. KotLER. 2001. Harvest rates and foraging strategies of Negev Desert gerbils. Behavioral Ecology 12: 219-226.

Price, M.V., N.M. Waser, and S. McDonald. 2000. Seed caching by heteromyid rodents from two communities: implications for coexistence. Journal of Mammalogy 81:97-106.

Reichman, O.J. 1975. Relation of desert rodent diets to available resources. Journal of Mammalogy 56: 731-751.

Reichman, O.J., And M.V. Price. 1993. Ecological aspects of heteromyid foraging. Pages 539-595 in H.H. Genoways and J.H. Brown, editors, Biology of the Heteromyidae. Special Publication, American Society of Mammalogists 10. $719 \mathrm{pp}$.
ReynoldS, H.G. 1958. The ecology of the Merriam kangaroo rat (Dipodomys merriami Mearns) on the grazing lands of southern Arizona. Ecological Monographs 28:111-127.

REYNOLDS, T.D., AND W.L. WAKKINEN. 1987. Characteristics of the burrows of four species of rodents in undisturbed soils in southeastern Idaho. American Midland Naturalist 118:245-250.

Schmidly, D.J., K.T. Wilkins, AND J.N. DerR. 1993. Biogeography. Pages 319-356 in H.H. Genoways and J.H. Brown, editors, Biology of the Heteromyidae. Special Publication, American Society of Mammalogists $10.719 \mathrm{pp}$.

SCHRODER, G.D. 1979. Foraging behavior and home range utilization of the bannertail kangaroo rat (Dipodomys spectabilis). Ecology 60:657-665.

SHAw, W.T. 1934. The ability of the giant kangaroo rat as a harvester and storer of seeds. Journal of Mammalogy 15:275-286.

Sipos, M.P., M.C. Andersen, W.G. Whitford, AND W.R. GoulD. 2002. Graminivory by Dipodomys ordii and Dipodomys merriami on four species of perennial grasses. Southwestern Naturalist 47:276-281.

TAPPE, D.T. 1941. Natural history of the Tulare kangaroo rat. Journal of Mammalogy 22:117-148.

Vander Wall, S.B., E.C.H. Hager, and K.M. Kuhn. 2005. Pilfering of stored seeds and the relative costs of scatter-hoarding versus larder-hoarding in yellow pine chipmunks. Western North American Naturalist 65:248-257.

Vorhies, C.T., AND W.P. TAYLOR. 1922. Life history of the kangaroo rat Dipodomys spectabilis spectabilis Merriam. United States Department of Agriculture Bulletin 1091. Washington, DC

Wнiтсомв, R.F. 1989. Nebraska Sand Hills: the last prairie. Proceedings of the North American Prairie Conference 11:57-69.

White, J.A. 2008. Placement and recovery of seed caches by a solitary rodent, Ord's kangaroo rat (Dipodomys ordii). Doctoral dissertation, Auburn University, Auburn, AL

Wilhite, D.A., and K.G. Hubbard. 1989. Climate. Pages 17-28 in A. Bleed and C. Flowerday, editors, An atlas of the Sand Hills. University of Nebraska-Lincoln, Conservation and Survey Division at the Institute of Agriculture and Natural Resources 5a:1-265.

Received 2 January 2009 Accepted 1 July 2009 